Article

\title{
Evaluation of Sustainable Rural Tourism. The Case of Uzundere District, Erzurum, Turkey +
}

\author{
Sanaz Davardoust ${ }^{1, *}$ and Faris Karahan ${ }^{2}$ \\ 1 Department of Architecture, Islamic Azad University, Kaleybar Branch, Kaleybar 5461963555, Iran \\ 2 Department of Landscape Architecture, Faculty of Architecture and Design, Atatürk University, \\ Erzurum 25240, Turkey; fkarahan@atauni.edu.tr \\ * Correspondence: sanaz@atauni.edu.tr; Tel.: +98-914-1196276 \\ + This study was developed from the PhD thesis entitled "Comparison of ecological architecture and \\ sustainable tourism approaches in rural landscapes of Erzurum and Tabriz" at Atatürk University.
}

Citation: Davardoust, S.; Karahan, F. Evaluation of Sustainable Rural Tourism. The Case of Uzundere District, Erzurum, Turkey. Sustainability 2021, 13, 10218. https:// doi.org/10.3390/su131810218

Academic Editor: Gema Cárdenas

Received: 3 July 2021

Accepted: 25 August 2021

Published: 13 September 2021

Publisher's Note: MDPI stays neutral with regard to jurisdictional claims in published maps and institutional affiliations.

Copyright: (c) 2021 by the authors. Licensee MDPI, Basel, Switzerland. This article is an open access article distributed under the terms and conditions of the Creative Commons Attribution (CC BY) license (https:// creativecommons.org/licenses/by/ $4.0 /)$.

\begin{abstract}
The Uzundere district, which is located in NE Turkey, has attractive rural tourism areas with noticeable potentials and rural tourism development activities. This paper concentrates on sustainability development of rural tourism. Sustainable tourism concentrates to conserve environmental and cultural resources and emphasizes on the responsibility of tourists and participation of local people for economic growth of the region. In this study, Delphi method is used to identify important factors for evaluating sustainable development of rural tourism in the Uzundere region. It consists of thirty-three indicators in four dimensions: service quality, facilities, management system, and results. Indicators are advisers for future tourism development activities at all levels of planning. These indicators plainly reflect the situation of area tourism. In this study, a questionnaire was prepared to evaluate the rural tourism developments in the Uzundere region, based on the Delphi method. Expert opinions were taken with the participation of ten experts of the region. This study showed that tourism development projects in this region are promising in order to achieve the goals of sustainable rural tourism. In addition, in cases identified during the research, there is a need to develop approaches and experiences to address the relevant shortcomings and deficiencies.
\end{abstract}

Keywords: rural tourism; sustainable development; sustainable rural; Uzundere; Turkey

\section{Introduction}

Since 1990, the Uzundere district, which is located in NE Turkey, has attracted national and international organizations' attention to its rich ecological values [1], where different projects have been started in various fields such as agriculture, environment, rural tourism, urbanism and architectural heritage. In the Uzundere region, pilot projects for rural tourism have been started while there is a dearth of research in sustainability development of rural tourism.

Rural tourism has experienced a great deal of growth over the past 20 years [2-5]. It further contributes to economic growth of the region [6-9]. Rural tourism provides the possibility of regional economic, socio-cultural and ecological sustainability [10,11]. Local development which may considers child labor should be such that that is does not affect their schooling; otherwise, it can increase the vulnerability of children and impede their well-being [12]. Agritourism activity is one of the proposals for sustainable development of rural world $[13,14]$. Although agritourism is one of the most popular activities [15] rural tourism is an idea wider than agritourism because it includes all available cultural activities taking place in rural areas [16,17] with social interactions between local communities, women without traditional limitations [18], men and tourism managers $[19,20]$ as there is a hidden positive social capital in rural communities [21]. Since the existing natural and cultural resources of the region are used to fulfill touristic activities, it is not possible to mention rural tourism without preserving the cultural and natural 
values, [22-27]. In this regard, it is significant to consider the satisfaction with the aesthetic experience of rural tourism and adjust progress strategies [28,29]. Traditional culture is an indispensable livelihood property for vernacular households [30,31] so requisite to empowering vernacular members is to decipher their opinions, beliefs and cultures [32]. In addition, nature conservation efforts improve household level livelihood [33]. Rural tourism offers wide variety of activities with less costly services and high-level comfort. In this kind of tourism, most usual types of booking are directly through the Internet, or via telephone or fax with no dominant role of large tour operators [34]. For rural tourism sustainability, it should managed by regional and local small enterprises [35-37]. In addition, social media has an important role in this industry as a marketing tool on tourists' decision-making and experience and also rural residents' tourism participation [38,39]. These online and easily accessible sources of information should be considered because they are part of daily lives of people [40].

\section{Literature Review}

The prominent feature of rural truism is sustainability of environment [41-46]. Proenvironmental behavior is one of the ways to achieve environmental sustainability [47]. Considering principles of indigenous environmental justice [48] sustainable rural tourism can be achieved through satisfaction of economic, cultural and legal demands raised by society $[49,50]$. Furthermore, tourists' expectations should be addressed in such a way that no harm is imposed to the unity, cultural identity, environmental health and economical balance of the destination [51-53]. In addition, the damage caused by overcrowding from excessive numbers of tourists should be considered [54]. To access sustainability in tourism, we need to understand the value gained from sustainability by different stakeholders in the tourism supply chain and also by users [55].

Sustainable rural tourism strategies have four special elements. These strategies that are formulized by an individual or a team are not only successful in development of tourism, but also in economic, ecologic and social analyses [56]. However, local areas are important motivators for rural tourism entrepreneurs [57], and there is a lack of research into local governance attitudes in rural tourism [58]. Determination of rural tourism destinations by providing low level planning, without Scientific Tourism and corruption on the tourism sector generates considerable economic, cultural and environmental drawback impacts [59-64]. Traditional factors that describe sustainable rural tourism are limited in terms of resources, activities and community-based sustainability concepts. Specialization in tourism enhances the sustainability of growth [65]. Sustainable tourism concentrates on environmental and cultural resources in order to conserve them and emphasizes on the responsibility of tourists and participation of local people.

Although rural tourism activities have increased dramatically in the study area, taken initiatives are not good enough to increase income for indigenous inhabitants. There is neither a common management framework nor indicators for regularly tracking and monitoring social, political and economic change in societies. Without evaluations or indicators for tourism development the use of the term 'sustainable' will be illogical and meaningless.

Delphi method is applied to develop indicators that measure sustainable rural tourism development within a sustainable framework. Delphi method systematically combines 'expert knowledge and opinion to achieve at an aware group consensus on a complex subject'. Delphi method identifies important factors for evaluating sustainable development of rural tourism. It consist of thirty-three indicators (Table 1$)$ in four dimensions: service quality ( 6 indicators), facilities (6 indicators), management system (15 indicators) and results (6 indicators) [66]. This paper demonstrates how an integrated approach can be successful in the sustainable development of rural tourism in the Uzundere region. Sustainable tourism indicators measure the actual impact of sustainable tourism development policies. It also increases the overall understanding of the region's problems and clearly states the environmental, social and economic problems and shortcomings of management 
strategies and lack of facilities in the region. Therefore, in order to provide educational, adventurous and enriching experiences for tourists based on various sources, the region is evaluated by Delphi method to see how they could become a rural tourist destination.

Table 1. Number of indicators developed from the Delphi study [66].

\begin{tabular}{|c|c|c|}
\hline & Dimensions & Number of Indicators Developed \\
\hline \multirow{2}{*}{ Service quality } & Accessibility & \multirow{2}{*}{6} \\
\hline & Convenience & \\
\hline \multirow{3}{*}{ Facility } & Accommodations & \multirow{3}{*}{6} \\
\hline & Subsidiary facilities & \\
\hline & Environment & \\
\hline \multirow{4}{*}{ Management system } & Community planning & \multirow{4}{*}{15} \\
\hline & Collaborated community business & \\
\hline & Community management & \\
\hline & Tourism business & \\
\hline \multirow{2}{*}{ Outcome } & Satisfaction & \multirow{2}{*}{6} \\
\hline & Income and total sales & \\
\hline
\end{tabular}

\section{Uzundere}

\subsection{Location of Uzundere}

Uzundere is located $84 \mathrm{~km}$ away from Erzurum and $116 \mathrm{~km}$ from Artvin and it is on the road of the Erzurum-Artvin and Tortum River (Figure 1). Uzundere is ecologically located in Eastern Anatolia Region, in the Eastern Black Sea Region. There is a considerable height difference between the valleys and hilly areas in this region. This difference varies from 600 to $3650 \mathrm{~m}$ [67]. The region lies at latitude $40.350^{\circ}$ north and longitude $41.500^{\circ}$ east. The Uzundere region has drawn the attention of national and international organizations since 1990 in terms of its ecological, agricultural, tourism, urbanization and architectural heritage and projects.

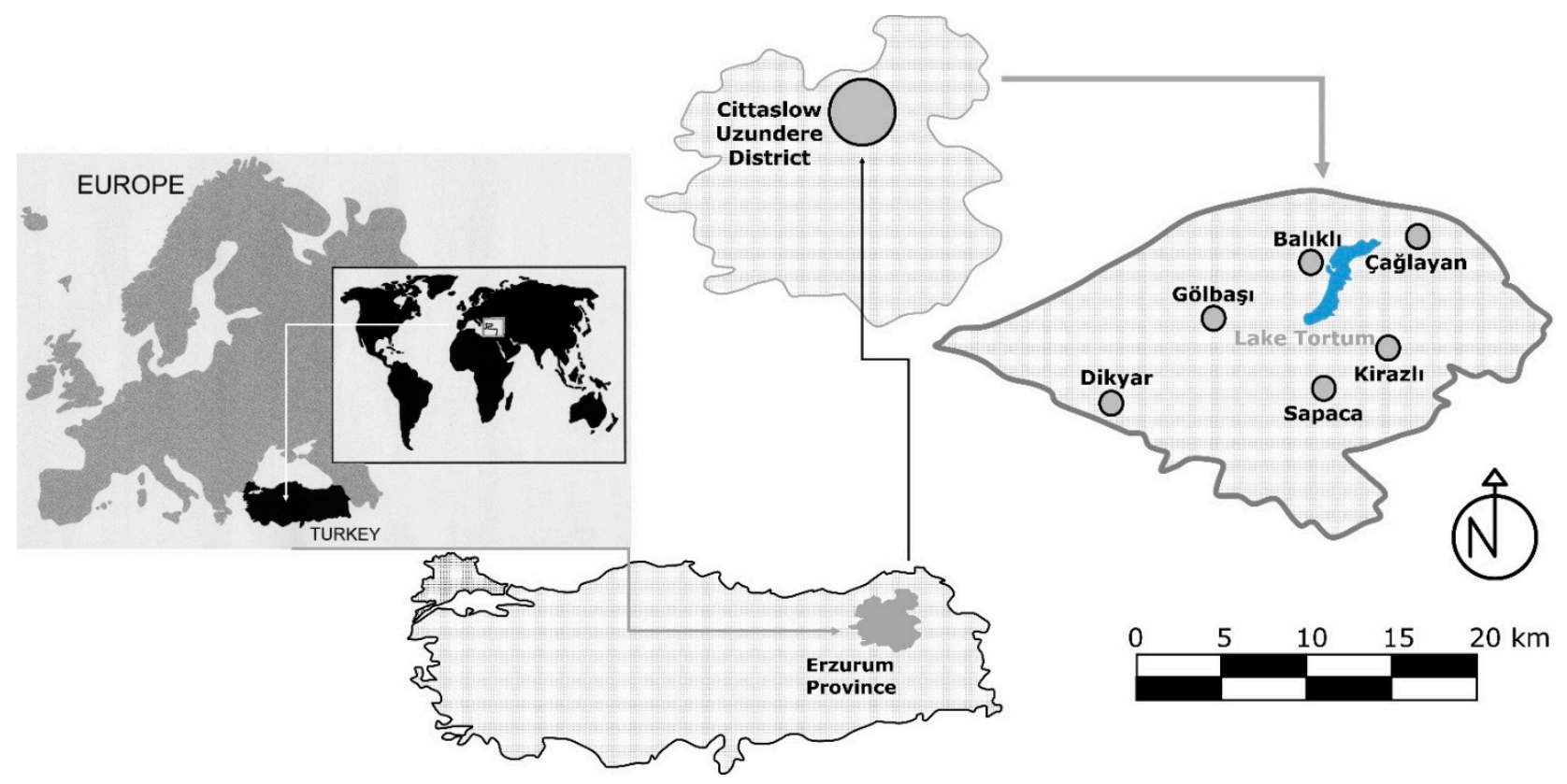

Figure 1. Location of research area. 


\subsection{Rural Tourism in Uzundere}

The Uzundere region has been in the rural landscape branch and its sub-branch has been agricultural landscape, in terms of landscape classification, until the early 1990s. Tourism and politics are symbiotic [68]. The Turkish Development Foundation developed tourism in the region in order to strengthen the economic structure of the region. Thus, Uzundere, which is located in one of the important branches of this valley, also became acquainted with the tourism industry after these years in its economic activities in the agriculture sector.

This trend in the Uzundere region (1) was started in 2007-2012 by the United Nations Development Program (UNDP) and the Eastern Anatolia Tourism Development Project (DATUR) of the Ministry of Culture and Tourism of the Republic of Turkey (2) between 2010 and 2018, with the support of the European Union, Ministry of Youth and Sports of the Republic of Turkey, Ministry of Interior of Turkey, Northern Anatolia Development Agency (KUDAKA), Regional Development Office, with the improvement of infrastructure, social relations, human capital, and institutional capacity building and entrepreneurship projects, most of which are related to tourism, and is continued. (3) As well as masters and doctoral theses conducted by Ataturk University, the Uzundere region is introduced as a destination for rural tourism. The Uzundere region was declared a tourist resort by the Council of Ministers of the Republic of Turkey in 2013 and was included in the Cittaslow international network in 2016.

The Uzundere region due to its rich natural and cultural resources hosts natural and cultural tourists yearly (Figure 2). In this region, social and organized tourism activities, such as the Eastern Anatolia International Youth Festival, under the wings of my Anoatolia, in which I have families in 81 cities, International bird watching festivals, International ice climbing festival, Traditional wrestling competitions, such as setting up boarding houses, physical tourism investments in hotels and accommodation were also realized. Creating opportunities associated with sport tourism and supplemental tourism activities can help regional and national tourism organizations to maximize the tourism benefits [69]. Generally, tourism activities in the Uzundere region are as follows: (1) In the field of cultural tourism, you can visit cultural heritage phenomena such as Engüzekkapı Castle, Öşk Monastery, Kireçli Bridge, İnçer Mosque, Sapaca Mosque, and Sapaca Castle. (2) In the field of water-based activities, you can name rafting, jet skiing, windsurfing and pedal boating on the lake. (3) In the field of doing nature activities you can name road and mountain biking, rope climbing and rock climbing, mountaineering, botanical activities, and photography with safari (Figure 3). (4) In the field of performing emotional and dramatic sports you can name ice climbing, rope jumping, wing suiting, and parachuting. (5) In addition finally holding festivals of traditional wrestling competitions and mountain festivals that are held in different villages can be named. 


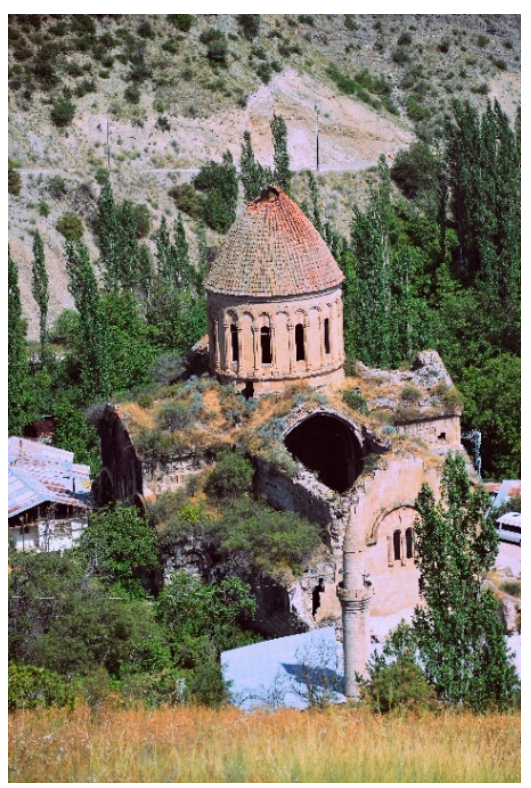

(a)

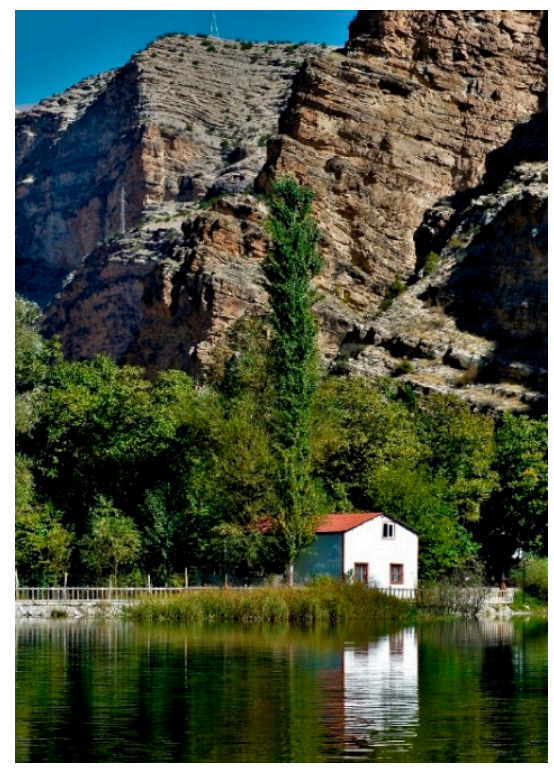

(b)

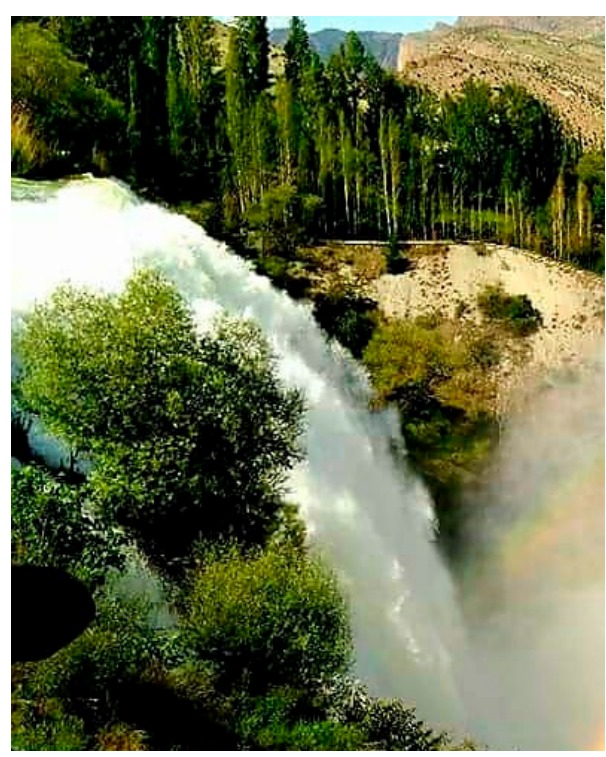

(c)

Figure 2. (a) Cultural heritage (Öşk Monastery), (b) Natural heritage (Yedi göller), (c) Natural heritage (Tortum waterfall).
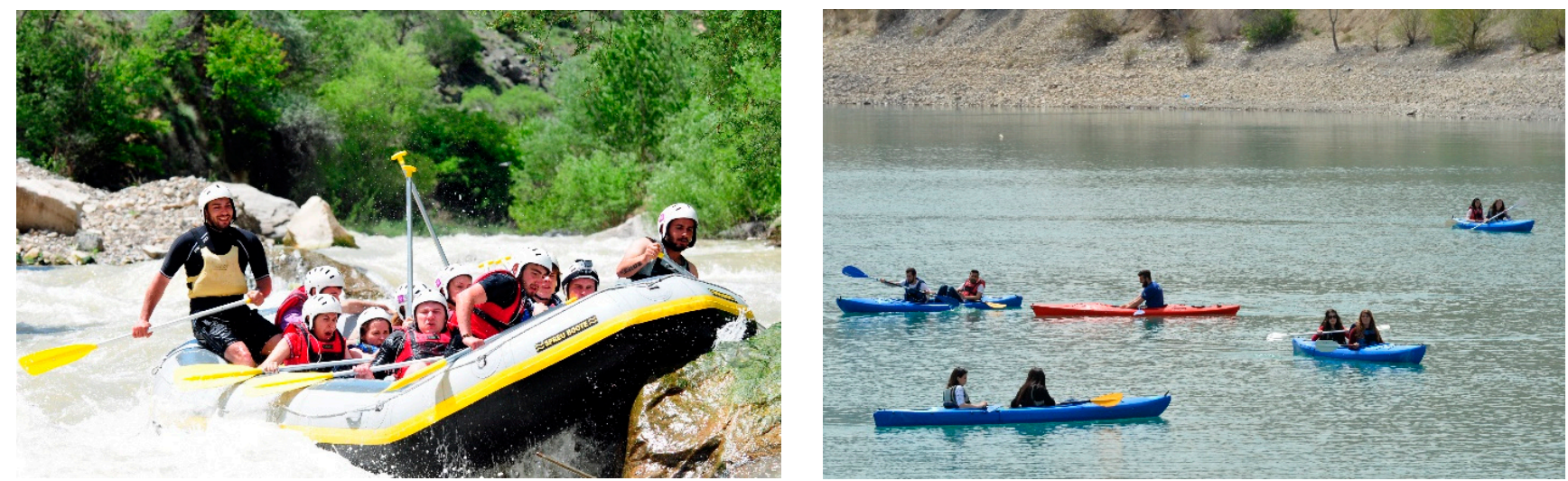

(a)
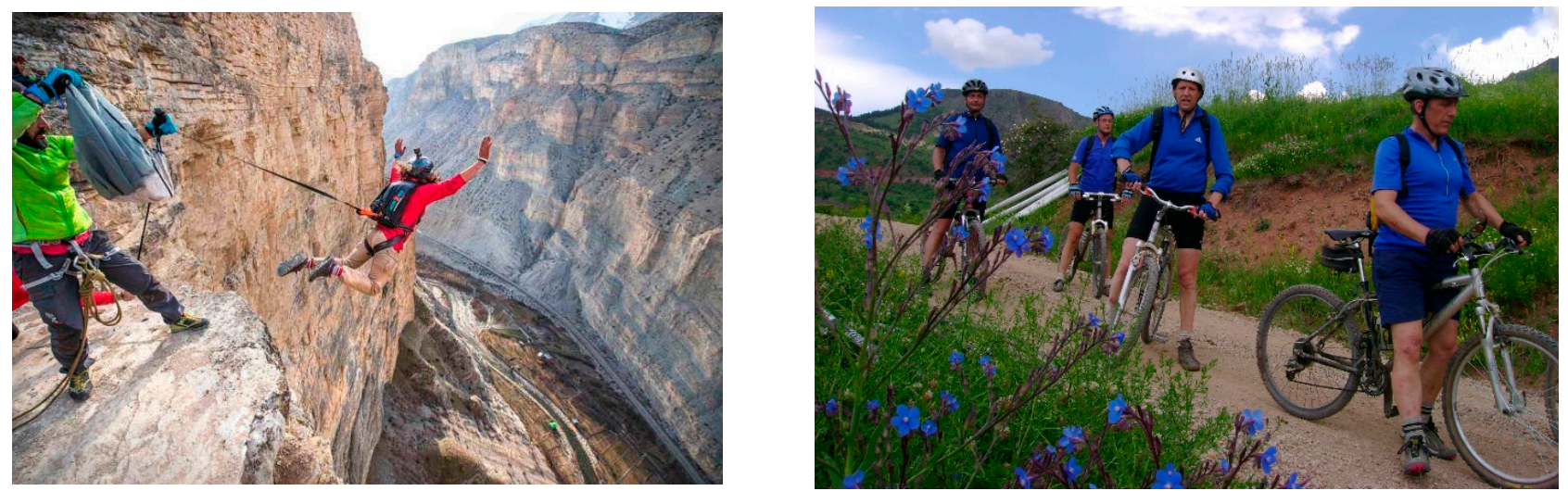

(b)

Figure 3. (a) Water-based activities (b) Nature activities. 


\section{Material and Method}

For beginning tourism activities in rural regions, first the areas and villages must be determined [70]. In this stage, the local people who have a special knowledge about their regions can help find tourism resources and socio-economic planning. Therefore, Uzundere, which is included in the study first, is analyzed to find the opportunities for experiencing adventures, suitable places and villages by tourists. The villages of Gölbaşı, Sapaca, Balıklı, Çağlayan, Dikyar, and Kirazlı in the Uzundere region (Figure 1) are suggested as tourism destinations. Since these villages have beautiful landscape, relaxing atmosphere, untouched rural areas, traditional and local food, cultural attractions and vegetation and flora, they are selected as destinations. Although all selected villages have these general features, each of them has specific features. For example, Gölbaşı village has agricultural lands, thousand years of history and cultural values. Sapaca village has ecological and traditional values. Balıklı village has a beautiful lake landscape. Çağlayan village has Tortum waterfall and lake, created by the Tortum River. Dikyar village has deep valleys and a topographic landscape and Kirazlı is a village where traditional ceremonies are held.

At this stage, a questionnaire was prepared to evaluate the rural tourism developments in the Uzundere region, based on the Delphi method. Expert opinions were taken with the participation of ten experts of the region. Our assessment is done in 4 dimensions and each dimension is divided to separate sub-dimensions studied separately: 1-Service quality: (a) Accessibility (b) convenience 2-Facility: (a) Accommodations (b) Subsidiary facilities (c) Environment 3-Management system: (a) Community planning (b) Collaborated community business (c) Tourism business 4-Outcome (a) Satisfaction (b) Income and total sales. The team of experts gave one of these answers (agree, strongly agree, no idea, disagree, strongly disagree) to each of 33 indicators. Finally, the collected of the answers is given as a percentage in Table 2. The scores of the answers were considered in five forms (score 1 for agree answers), (score 2 for strongly agree answers), (score 0 for no idea answers), (score -1 for disagree answers) and (score -2 for strongly disagree answers). If $100 \%$ expert group answers are strongly agree and as mentioned the score of strongly agree is 2 , the maximum score will be 200 (percentage $=100 \%$ ). Then, based on this scoring, a separate percentage was calculated for each indicator and shown in Figure 4 as a graphical shape. Expert group answers for each indicator vary from (strongly disagree $=-100 \%$ ) to (strongly agree $=100 \%$ ).

Table 2. Evaluation of sustainable rural tourism indicators in the Uzundere region.

\begin{tabular}{|c|c|c|c|c|c|c|c|}
\hline \multirow[b]{2}{*}{ Dimension } & \multirow[b]{2}{*}{ Category } & \multirow[b]{2}{*}{ Indicators } & \multicolumn{5}{|c|}{ Percentage (\%) } \\
\hline & & & $\begin{array}{l}\text { Strongly } \\
\text { Disagree }\end{array}$ & Disagree & $\begin{array}{c}\text { No } \\
\text { Idea }\end{array}$ & Agree & $\begin{array}{c}\text { Strongly } \\
\text { Agree }\end{array}$ \\
\hline \multirow{6}{*}{$\begin{array}{l}\text { Service } \\
\text { quality }\end{array}$} & \multirow{3}{*}{ Accessibility } & Reservation system on homepage & 0 & 0 & 30 & 50 & 20 \\
\hline & & Fit tourist guide book and map & 0 & 0 & 20 & 50 & 30 \\
\hline & & Equip a directional sign to the village within $5 \mathrm{~km}$ & 0 & 0 & 20 & 30 & 50 \\
\hline & \multirow{3}{*}{ Convenience } & Ratio of householders who has checklists for bedding & 50 & 30 & 20 & 0 & 0 \\
\hline & & Using credit card for paying a fee & 50 & 20 & 30 & 0 & 0 \\
\hline & & Number of people who took lectures on rural tourism & 0 & 0 & 20 & 50 & 30 \\
\hline \multirow{6}{*}{ Facility } & \multirow{3}{*}{ Accommodations } & Ratio of rooms isolated from host family house & 10 & 20 & 30 & 40 & 0 \\
\hline & & Ratio of rooms with flush toilet & 0 & 30 & 40 & 30 & 0 \\
\hline & & Ratio of rooms with shower bath & 0 & 30 & 40 & 30 & 0 \\
\hline & \multirow{2}{*}{$\begin{array}{l}\text { Subsidiary } \\
\text { facilities }\end{array}$} & Meeting room with about 20 people capacities & 0 & 10 & 40 & 40 & 10 \\
\hline & & Parking lots that hold over 20 cars & 0 & 100 & 0 & 0 & 0 \\
\hline & Environment & Refuse disposal system in their community & 0 & 0 & 0 & 60 & 40 \\
\hline
\end{tabular}


Table 2. Cont.

\begin{tabular}{|c|c|c|c|c|c|c|c|}
\hline \multirow[b]{2}{*}{ Dimension } & \multirow[b]{2}{*}{ Category } & \multirow[b]{2}{*}{ Indicators } & \multicolumn{5}{|c|}{ Percentage $(\%)$} \\
\hline & & & $\begin{array}{l}\text { Strongly } \\
\text { Disagree }\end{array}$ & Disagree & $\begin{array}{l}\text { No } \\
\text { Idea }\end{array}$ & Agree & $\begin{array}{l}\text { Strongly } \\
\text { Agree }\end{array}$ \\
\hline \multirow{15}{*}{$\begin{array}{l}\text { Management } \\
\text { system }\end{array}$} & \multirow{3}{*}{$\begin{array}{l}\text { Community } \\
\text { planning }\end{array}$} & Long-term community plan for latest three years & 10 & 40 & 40 & 10 & 0 \\
\hline & & Fund-raising on their community & 0 & 0 & 30 & 50 & 20 \\
\hline & & Number of expert consultation for developing tourism & 0 & 0 & 30 & 50 & 20 \\
\hline & \multirow{4}{*}{$\begin{array}{l}\text { Collaborated } \\
\text { community } \\
\text { business }\end{array}$} & Community festival & 0 & 0 & 0 & 30 & 70 \\
\hline & & Ratio of householder with tourism management diary & 0 & 20 & 70 & 10 & 0 \\
\hline & & $\begin{array}{l}\text { Value-added processing businesses in their } \\
\text { community }\end{array}$ & 0 & 10 & 10 & 40 & 40 \\
\hline & & $\begin{array}{l}\text { Amount of Internet sales for their own products in } \\
\text { their community }\end{array}$ & 20 & 60 & 20 & 0 & 0 \\
\hline & \multirow{4}{*}{$\begin{array}{l}\text { Community } \\
\text { management }\end{array}$} & $\begin{array}{l}\text { Minutes and account book for community council } \\
\text { meetings }\end{array}$ & 20 & 30 & 40 & 10 & 0 \\
\hline & & Propaganda within latest three years & 0 & 0 & 10 & 30 & 60 \\
\hline & & $\begin{array}{c}\text { Organizing and participating in local tourism } \\
\text { development council }\end{array}$ & 0 & 10 & 10 & 30 & 50 \\
\hline & & Enacting community agreements & 0 & 10 & 20 & 50 & 20 \\
\hline & \multirow{4}{*}{$\begin{array}{l}\text { Tourism } \\
\text { business }\end{array}$} & $\begin{array}{c}\text { Ratio of householder participating in community } \\
\text { tourism business }\end{array}$ & 0 & 0 & 20 & 50 & 30 \\
\hline & & Full time worker to managing their tourism business & 0 & 0 & 0 & 40 & 60 \\
\hline & & Insurance for visitors & 30 & 40 & 30 & 0 & 0 \\
\hline & & Constructing customer database & 10 & 20 & 50 & 20 & 0 \\
\hline \multirow{6}{*}{ Outcome } & \multirow{2}{*}{ Satisfaction } & Residents' satisfaction & 0 & 0 & 30 & 60 & 10 \\
\hline & & Visitors' satisfaction & 0 & 0 & 20 & 60 & 20 \\
\hline & \multirow{4}{*}{$\begin{array}{l}\text { Income and } \\
\text { total sales }\end{array}$} & Increasing rate of a number of visitors & 0 & 0 & 30 & 40 & 30 \\
\hline & & Increasing rate of direct sales & 0 & 10 & 30 & 60 & 0 \\
\hline & & Number of one company one village linkage & 20 & 40 & 40 & 0 & 0 \\
\hline & & Ratio of equity capital per government assistance & 0 & 10 & 50 & 40 & 0 \\
\hline
\end{tabular}

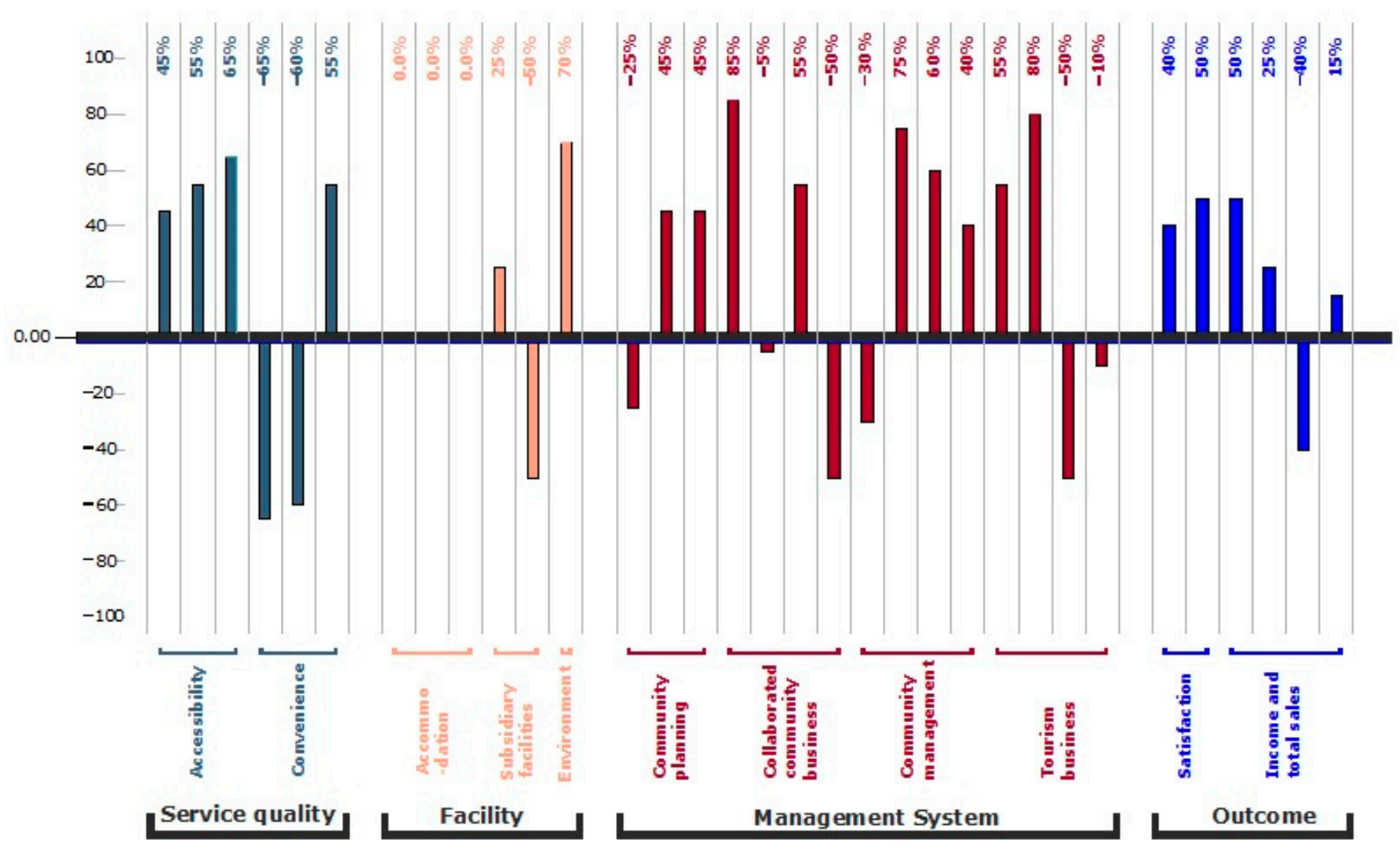

Figure 4. Graphical form of evaluation of sustainable rural tourism indicators in the Uzundere region. 
The result of evaluation of sustainable rural tourism indicators by Delphi method can be utilized in rural tourism practices in the Uzundere region. Based on the evaluation of the results suggestions are offered for the studied regions to be rural tourist destinations. These suggestions will aid regional and local stakeholders in the stage of tourism planning as principles in future tourism development.

\section{Evaluation of Sustainable Rural Tourism Indicators in Studied Region \\ 4.1. Evaluation of Service Quality in Regions}

According to Table 2, the assessment of Accessibility category of Service Quality dimension shows that homepages are used effectively in terms of providing advertising service, guidance and reservation in Uzundere. The responses of the expert group were evaluated as below: 30\% no idea, 50\% agree and 20\% strongly agree. According to the description of previous section the score of this indicator will be $90(30 \times 0+50 \times 1+20 \times 2)$ and as max score is 200 the percentage of this indicator will be $45 \%$. Similarly, the percentage of other indicators was calculated and is shown in Figure 4 . The infrastructure of tourists' access to products and services via the web and the internet has been started in Uzundere, and this is expected to improve in the medium and long terms. On the other hand, the $30 \%$ of (no idea) responses, is followed by this theory that, except Uzundere Municipality and Uzundere Governorship, pensions and other recreational centers do not have Internet-based access policies for customers. In the Accessibility category, it is concluded that access to suitable books and tourist maps for the Uzundere Valley is $80 \%$ positive (50\% agree $+30 \%$ strongly agree). The United Nations Development Program (UNDP) done between 2007 and 2012 years and the Eastern Anatolia Tourism Development Project (DATUR) implemented with coordination of the Ministry of Culture and Tourism, plays an outstanding and important role in revealing the potential of local tourism. Publishing and distributing books and tourist maps with the implementation of the DATUR project in the region, especially the activities of Uzundere Municipality, is also at a desirable level. In the third and final part of the Accessibility category, related to installing signboards $5 \mathrm{~km}$ to the villages, the response of the expert group was $80 \%$ positive (30\% agree and $50 \%$ strongly agree). The answer indicates that the transportation infrastructure and installing road signs in the Uzundere valley is enough. On the other hand, the answer of $20 \%$ of experts as "I have no idea" is interpreted as the need to improve the study of signs or marketing methods related to tourism services.

For the assessments made in the category of Convenience at the level of service quality, first the number of rented rural houses for tourists was examined. In these areas residents transform their living spaces into shared multi-functional spaces for tourists and themselves [71]. The expert group answered 50\% strongly disagree, 30\% disagree and $20 \%$ no idea, respectively. The results show that the owners of rented rural houses in the Uzundere region have not taken the initiative and work plan in this regard. Then, the possibility of using a credit card was examined and it is compared with similar previous answers so it is concluded that there are no payment facilities via credit card, and traditional methods are preserved. In the third stage of this category, the number of presented conferences on the topic of rural tourism was examined. The group of experts answered $20 \%$ no idea, 50\% agree, and 30\% strongly agree respectively.

\subsection{Evaluation of Facilities in Regions}

For the assessments made in the category of facility at the level of Accommodation, first of all, the number of rental houses were examined. There was no specific orientation in the classification of the answers given by the group of experts. The answers are $10 \%$ strongly disagree, $20 \%$ disagree, $30 \%$ no idea and $40 \%$ agree respectively. It seems there is no practical study for the study of the region yet, and the response of $40 \%$ agree, should be considered as an optimistic expectation for the region. The same situation is observed in the same subset for the options of, the existence of toilets and bathrooms in the rooms. In fact, the percentages of both subsets are rated 30\% disagree, $40 \%$ no idea, and 30\% 
agree respectively. According to the investments made in the tourist infrastructure and the programs implemented in the last 15 years by the local government, governmental and non-governmental organizations in the Uzundere region, and also according to the survey results, there is no accommodation problem in the region. In addition, the Boutique Hotel in Uzundere, the Karshilama Center (now the Teachers' House), and the Uzundere Cultural Municipality Center, are ready to provide services in this area.

For the assessment made in the category of the facility at the level of subsidiary facilities, first, the option of a conference room with a capacity of 20 people was examined. The results of the survey were $10 \%$ disagree, $40 \%$ no idea, $40 \%$ agree and $10 \%$ strongly agree, respectively. Making investments for places such as hotels, youth centers, and cultural centers in the Uzundere region, helps to develop the minimum standard of meeting space in different categories, but it cannot be said that these spaces are enough nor that the use of these spaces is reasonable. Then the option of having a parking lot with a capacity of 20 cars was assessed, in this subset. The result of the assessment, is that $100 \%$ disagree can be convincing because infrastructure investments in the Uzundere do not adequately have any planning for a parking lot.

For the assessment made in the category of the facility at the level of environment, the group of experts in the Uzundere region have expressed their answers to the questionnaire about the existence of a waste disposal system. The answers are $60 \%$ agree and $40 \%$ strongly agree, respectively. Thus, it seems that the Uzundere region, in terms of collecting and disposing of solid waste, is in a good condition, the methods of Uzundere and Erzurum municipalities are sufficient and there are no significant problems of solid waste disposal in the region.

\subsection{Evaluation of Management System in Regions}

For the assessment made in the category of management system at the level of community planning, the given answers to the questionnaire about a three-year (long-term) planning in the Uzundere region are $10 \%$ strongly disagree, $40 \%$ disagree, $40 \%$ no idea and $10 \%$ strongly agree. As a result, it is concluded that people are not sufficiently aware of the strategic planning, strategic development, comprehensive tourism plan, biodiversity strategy plan and operational plans prepared in the Uzundere region. As a second component of this category, supporting of local people was assessed and the responses were $30 \%$ no idea, $50 \%$ agree and $20 \%$ strongly agree, so the positive answers were above $70 \%$, which is interpreted as that people are supported by local government, as well as public and universities. The third component of this category is the existence of expert advice in the field of tourism development and, as in the previous component, a positive response of over $70 \%$ has been evaluated by a group of experts, which shows the support of local government civil society, universities and some international organizations.

For the assessment made in the category of management system at the level of collaborated community, the first component that is holding the festivals, shows that the experts answered 30\% agree and 70\% strongly agree. This situation shows that in this region festivals are held based on a deep and rooted culture of a thousand years. However, considering the $70 \%$ no idea responses to the component, and the ratio of rental houses with tourism management, we conclude that there is a long way to go for improving this matter. On the one hand, it is important that existing tourism jobs help local people and the economy. On the other hand, the component of determining value-added during rural tourism activity is confirmed by expert groups with $80 \%$ positive response. However, regarding the number of online sales of local products in the region, $80 \%$ answered that local people cannot use technology effectively, and the existence of traditional methods is considered as an effective method.

For the assessments made in the category of management system in the level of management community, in the first component, the number of hours and meetings and regional councils are 20\% strongly disagree, 30\% disagree, $40 \%$ no idea, and 10\% agree respectively. The assessment is considered as a method of record-keeping which is 
not yet developed in jobs, local government, and governmental and non-governmental organizations in the Uzundere region. On the other hand, the propaganda in the latest three years, which is in the same category, is evaluated with $90 \%$ positive response. The improvement in this situation is due to the implementation of the DATUR project and the existence of Internet advertising channels and printed brochures, catalogs, and guides. The level of interest of local people in tourism development participation and strategy preparation meetings discussed in this section is assessed as $80 \%$ positive. In fact, this result can be further explained by the experience of implementing DATUR, KUDAKA projects, the Regional Development Office, ministerial support and tourism, and rural development initiatives, such as the LEADER program, which has been implemented in the Uzundere region. In the category of community management, there is a $70 \%$ positive response in the component of enacting community agreement, and this result is due to the fact that the people of this region cooperate with each other in environmental and social events.

According to the assessment done in the category of management system at the level of tourism business, it was observed that the ratio of householder participating in community tourism business in the Uzundere region has a positive trend of $80 \%$. This situation can be explained by the low population density of the region and the fact that the businesses in this region are familiar with each other, the local people, and the visitors. It also shows the interest of local people in social and environmental events. The second component in the implementation of tourism activities in this category is the number of full-time workers in this industry, which has been $100 \%$ confirmed by experts, and the importance of this situation for the development of rural tourism and the sustainability of local economic activities is significant. For the third component of this category, which is the insurance of visitors, the answers of experts is 30\% no idea, 30\% strongly disagree, and $40 \%$ disagree. The results show that this issue has been largely ignored by companies in the Uzundere region, or there is no information or awareness about this issue. One of the important issues in the category of tourism management is creating a database for customers and visitors. For the Uzundere region, only $20 \%$ of experts think such a database exists, while the rest either have no idea $(50 \%)$, or $30 \%$ believe there is no such database.

\subsection{Evaluation of Tourism Outcome in Regions}

In the assessments made in the satisfaction category at the level of residents' satisfaction, it is observed that the level of satisfaction of dormitory owners in the Uzundere region has had $70 \%$ positive progress. The respondents often believe that the relative increase in the number of visitors to Uzundere, the re-use of dormitories by visitors, and the role of tourism in the family economy as a source of additional income, besides the agricultural livelihoods in the past are important factors in this development. The second component of this category is visitors' satisfaction. The survey results show that $80 \%$ of visitors are satisfied with rural tourism activities in Uzundere. However, the $20 \%$ no idea responses as well as the previous section may be due to the fact that so far no studies have been conducted to measure visitors' satisfaction.

The assessments made in the category of the outcome at the level of total sales and income show that the increase of visitors' number in the Uzundere region is 70\%, and the rate of increase in sales of local products is $60 \%$. Despite the increase in the number of visitors and the increase in the sale of local products directly, the survey results of $60 \%$ disagree and $40 \%$ no idea indicate that there has not been any travel tour to Uzundere region and its villages so far.

\section{Conclusions}

In a rural area, the most important infrastructure of tourism is the intangible and tangible cultural heritage of the past as well as agricultural landscape and products. In addition to maintaining the natural and cultural values of the area, this industry in the concept of sustainable tourism is closely dealt with the economic, ecological, spatial, and participatory processes. The Uzundere rural tourism development activities that 
were started with the Development of East Anatolia Tourism Project (DATUR) have been financed by the regional development agency and other national-international funds and the tourism center for 15 years. In addition, this area has been included in the Cittaslow international network since 2016.

Many studies have been done in this area in the field of rural tourism but the indications in this study are at the community level to evaluate and monitor community-based sustainable rural tourism projects. Indicators are advisers for future tourism development activities at all levels of planning. These indicators operate in such a way that they plainly reflect the situation of area tourism. Indicators include issues such as assisting regional and local stakeholders in tourism planning. Residents' participation is very important because they are a major stakeholder in rural tourism destinations. Training of stakeholders should be a top priority because lack of stakeholder awareness and participation has been one of the major failures in implementing indicators at the local level. From a practical point of view, the quality of services, facilities, village management, environmental protection and tourism outcomes are all urgent issues that need to be addressed. These indicators can help the government ensure that these policies are implemented properly.

Conducting a survey by a group of experts in 4 dimensions and 33 indicators, the present study provided clues about the future of tourism in the area. As shown in Figure 4, the experts' answers to 20 indicators (out of 33) were evaluated positively (percentage above zero). This showed that the tourism development projects in this area to benefit from sustainable rural tourism purposes are promising. The zero or below zero evaluations indicated the development of approaches and experiences to resolve the relevant shortcomings and deficiencies.

In this regard, it is revealed that Uzundere valley is completely identified in the TRA1 area and Erzurum Province. It is also easily accessible from the two regions of the Eastern Back Sea and East Anatolia, and it is a tourism destination of both regions. The location of Uzundere is also good for tour plans and organizations of Georgia. However, their efforts to build innovative hotels and holiday villages for residential infrastructure are not satisfactory. In this regard, protection the natural landscape belt placed between the center of Uzundere and the Yedigoller region (Lake Tortum, geological formations, Tortum Falls) and encouragement to use the native architectural design principles for this end contribute to the sustainable development of the industry and guarantee the natural and cultural landscape protection. Moreover, since the area is a rural area, it is difficult to find native human resources who can speak international languages and use informationcommunication infrastructure for tourism purposes, or sell the indigenous products online. The result of rural sustainable tourism evaluation by Delphi indicators can be used in rural tourism activities in Uzundere, contributing to the government to regularly supervise the interaction of stakeholders and prevent poor decisions that may hinder sustainable development of rural tourism in the area.

Author Contributions: Conceptualization, S.D. and F.K.; methodology, S.D.; software, S.D.; validation, S.D., F.K..; formal analysis, S.D.; investigation, S.D.; resources, S.D.; data curation, S.D.; writing—original draft preparation, S.D.; writing—review and editing, S.D.; visualization, S.D.; supervision, S.D.; project administration, S.D.; funding acquisition, F.K. All authors have read and agreed to the published version of the manuscript.

Funding: This research received no external funding.

Institutional Review Board Statement: Not applicable.

Informed Consent Statement: Informed consent was obtained from all subjects involved in the study.

Data Availability Statement: Not applicable.

Conflicts of Interest: The authors declare no conflict of interest. 


\section{References}

1. Özgeriş, M.; Karahan, F. Use of geopark resource values for a sustainable tourism: A case study from Turkey (Cittaslow Uzundere). Environ. Dev. Sustain. 2021, 23, 4270-4284. [CrossRef]

2. Tremblay, P. Desert Tourism Scoping Study; Desert Knowledge CRC: Alice Springs, Australia, 2006.

3. Ferrari, G.; Vargas-Vargas, M. Environmental sustainable management of small rural tourist enterprises. Int. J. Environ. Res. 2010, 4, 407-414.

4. Leco, F.; Pérez, A.; Hernández, J.; Campón, A. Rural tourists and their attitudes and motivations towards the practice of environmental activities such as agrotourism. Int. J. Environ. Res. 2013, 7, 255-264.

5. Cason, D.A.; Koster, R. Theoretical Perspectives on Pural Tourism Development. In Demystifying Theories in Tourism Research; Bricker, K., Donohoe, H., Eds.; CABI Publishing: Oxfordshire, UK, 2015.

6. Mutlu Danac1, H.; Gülten, R.E. Ecotourism and Vernacular Architecture in Koprulu Canyon. J. World Turks 2013, 5, 41-46.

7. Saarinen, J.; Lenao, M. Integrating tourism to rural development and planning in the developing world. Dev. South. Afr. 2014, 31, 363-372. [CrossRef]

8. Winter, T.; Kim, S. Exploring the relationship between tourism and poverty using the capability approach. J. Sustain. Tour. 2020, 29, 1655-1673. [CrossRef]

9. Korani, Z.; Shafiei, Z. In search of traces of 'The Tourist Gaze'on locals: An ethnographic study in Garmeh village, Iran. J. Tour. Cult. Chang. 2020, 1-19. [CrossRef]

10. Yun, H.J. Spatial Relationships of Cultural Amenities in Rural Tourism Areas. Tour. Plan. Dev. 2014, 11, 452-462. [CrossRef]

11. Ivona, A. Sustainability of Rural Tourism and Promotion of Local Development. Sustainability 2021, 13, 8854. [CrossRef]

12. Cruz Jiménez, G.; Serrano-Barquín, R.d.C.; Zizumbo Villarreal, L.; Vargas Martínez, E.E. Child Labor and Child Work in the Touristic Sector of Cozumel and Valle de Bravo, Mexico. Int. J. Hosp. Tour. Adm. 2020, 1-24. [CrossRef]

13. Ciolac, R.; Iancu, T.; Brad, I.; Popescu, G.; Marin, D.; Adamov, T. Agritourism Activity-A "Smart Chance" for Mountain Rural Environment's Sustainability. Sustainability 2020, 12, 6237. [CrossRef]

14. Belliggiano, A.; Garcia, E.C.; Labianca, M.; Valverde, F.N.; De Rubertis, S. The "Eco-Effectiveness" of Agritourism Dynamics in Italy and Spain: A Tool for Evaluating Regional Sustainability. Sustainability 2020, 12, 7080. [CrossRef]

15. Choo, H.; Park, D.-B. The Role of Agritourism Farms' Characteristics on the Performance: A Case Study of Agritourism Farm in South Korea. Int. J. Hosp. Tour. Adm. 2020, 1-14. [CrossRef]

16. Bramwell, B.; Lane, B. Rural tourism and sustainable rural development. Proceedings of the Second International School in Rural Development, 28 June-9 July 1993, University College, Galway, Ireland. J. Sustain. Tour. 1994, 2, 1-129. [CrossRef]

17. Pechlaner, H.; Bialk-Wolf, A.; Zacher, D. The Role of Cultural Activities in Tourism Development: An Urban-Rural Perspective. Tour. Cult. Commun. 2015, 15, 47-58. [CrossRef]

18. Uduji, J.I.; Okolo-Obasi, E.N.; Onodugo, V.A.; Nnabuko, J.O.; Adedibu, B.A. Corporate social responsibility and the role of rural women in strengthening agriculture-tourism linkages in Nigeria's oil producing communities. J. Tour. Cult. Chang. 2020, 1-27.

19. Foley, C.; Grabowski, S.; Small, J.; Wearing, S. Women of the Kokoda: From Poverty to Empowerment in Sustainable Tourism Development. Tour. Cult. Commun. 2018, 18, 21-34. [CrossRef]

20. White, A.; Jones, E.; James, D. There's a nasty smell in the kitchen! Gender and power in the tourism workplace in Wales. Tour. Cult. Commun. 2005, 6, 37-49. [CrossRef]

21. Brouder, P. Creative outposts: Tourism's place in rural innovation. Tour. Plan. Dev. 2012, 9, 383-396. [CrossRef]

22. Blangy, S.; Mehta, H. Ecotourism and ecological restoration. J. Nat. Conserv. 2006, 14, 233-236. [CrossRef]

23. Danacı, H.M.; Atık, M. Rural Tourism and Vernacular Architecture: An Example from Elmalı, Antalya. Am. Int. J. Contemp. Res. 2014, 4, 69-72.

24. MacDonald, R.; Jolliffe, L. Cultural rural tourism: Evidence from Canada. Ann. Tour. Res. 2003, 30, 307-322. [CrossRef]

25. Khabbazi, A.P.; Yazgan, M.E. Kirsal Peysaj ve Ekoturizm. Uluslararası Sos. Ekon. Bilimler Derg 2012, 2, 5-9.

26. Somões, O.; Almeida Carreira, V. Póvoa Dão Village: An Instance of. Tour. Cult. Commun. 2012, 12, 19-28. [CrossRef]

27. Davis, P. Ecomuseums and the democratization of cultural tourism. Tour. Cult. Commun. 2004, 5, 45-58. [CrossRef]

28. Zhou, W.; Chen, L.-Y.; Chou, R.-J. Important Factors Affecting Rural Tourists' Aesthetic Experience: A Case Study of Zoumatang Village in Ningbo. Sustainability 2021, 13, 7594. [CrossRef]

29. Özgeriş, M.; Karahan, F. Kalkınma Odaklı Mekânsal Tasarım ve Uygulama Girişimlerinin Sürdürülebilirliğinin Değerlendirilmesi: Sakin Şehir Uzundere Örneğinde Bir Çalışma. Bartın Orman Fakültesi Derg. 2021, 23, 45-58.

30. Ma, X.; Wang, R.; Dai, M.; Ou, Y. The influence of culture on the sustainable livelihoods of households in rural tourism destinations. J. Sustain. Tour. 2020, 29, 1-18. [CrossRef]

31. Dias, Á.; González-Rodríguez, M.R.; Patuleia, M. Developing poor communities through creative tourism. J. Tour. Cult. Chang. 2020, 1-21. [CrossRef]

32. Sarr, B.; Sène-Harper, A.; Gonzalez-Hernandez, M.M. Tourism, social representations and empowerment of rural communities at Langue de Barbarie National Park, Senegal. J. Sustain. Tour. 2020, 29, 1383-1402. [CrossRef]

33. Nepal, S.K.; Lai, P.-H.; Nepal, R. Do local communities perceive linkages between livelihood improvement, sustainable tourism, and conservation in the Annapurna Conservation Area in Nepal? J. Sustain. Tour. 2021, 1-20. [CrossRef]

34. Serra Cantallops, A.; Ramon Cardona, J.; Estades Muntaner, R. Characteristics and peculiarities of rural tourism in the Balearic Islands. Tour. Plan. Dev. 2015, 12, 125-144. [CrossRef] 
35. Anderson, E.; Bakir, A.; Wickens, E. Rural tourism development in Connemara, Ireland. Tour. Plan. Dev. 2015, 12, 73-86. [CrossRef]

36. Qu, M.; McCormick, A.; Funck, C. Community resourcefulness and partnerships in rural tourism. J. Sustain. Tour. 2020, 1-20. [CrossRef]

37. Giampiccoli, A.; Mtapuri, O.; Nauright, J. Tourism development in the Seychelles: A proposal for a unique community-based tourism alternative. J. Tour. Cult. Chang. 2020, 19, 1-14. [CrossRef]

38. Senyao, S.; Ha, S. How social media influences resident participation in rural tourism development: A case study of Tunda in Tibet. J. Tour. Cult. Chang. 2020, 1-20. [CrossRef]

39. Joseph, A.I.; Peter, S.; Anandkumar, V. Development of a Typology of Tourists Based on Pre-trip Use of Social Media. Int. J. Hosp. Tour. Adm. 2020, 1-29. [CrossRef]

40. Huete-Alcocer, N.; Valero-Tévar, M.Á. Impact of Information Sources on Promoting Tourism in a Rural Region: The Case of the Roman Villa of Noheda. Sustainability 2021, 13, 8038. [CrossRef]

41. Durak, S.; Erbil, Y.; Akıncitürk, N. Sustainability of an architectural heritage site in Turkey: Fire risk assessment in Misi village. Int. J. Archit. Herit. 2011, 5, 334-348. [CrossRef]

42. Garcia-Esparza, J.A. Revitalization of architectural and ethnological heritage: Recovery of vernacular building techniques in a 19th-century winery. Int. J. Archit. Herit. 2014, 8, 140-159. [CrossRef]

43. Akgün, A.A.; Baycan, T.; Nijkamp, P. Rethinking on sustainable rural development. Eur. Plan. Stud. 2015, 23, 678-692. [CrossRef]

44. Tunçoku, S.S.; İnceköse, Ü.; Akış, T.; Yalçın, M.A. Assessment of construction techniques and material usage in Izmir rural houses. Int. J. Archit. Herit. 2015, 9, 1005-1022. [CrossRef]

45. Sbarcea, M.; Tudor, M. Tradition and modernity in Danube Delta architecture contemporary intervention towards sustainable settings. J. Environ. Prot. Ecol. 2016, 17, 1194-1202.

46. Karahan, F.; Davardoust, S. Sürdürülebilir Kirsal Kalkinma Için Yöresel Mimari: Keleyber Bölgesi (Iran) Örneği. ATA Planlama ve Tasarm Dergisi 2019, 3, 59-68.

47. Wu, J.; Font, X.; Liu, J. Tourists' Pro-environmental Behaviors: Moral Obligation or Disengagement? J. Travel Res. 2020, 60, 735-748. [CrossRef]

48. Jamal, T.; Higham, J. Justice and ethics: Towards a new platform for tourism and sustainability. J. Sustain. Tour. 2021, 29, 143-157. [CrossRef]

49. Slabbert, E.; du Plessis, E.; Digun-Aweto, O. Impacts of tourism in predicting residents' opinions and interest in tourism activities. J. Tour. Cult. Chang. 2020, 1-19. [CrossRef]

50. Özgeriş, M.; Karahan, F. Yerel Kalkınmanın Aracı Olarak Sürdürülebilir Turizm için Planlama Çalışmalarının Değerlendirilmesi: Sakinşehir Uzundere Örneğinde Bir Araştırma. Kent Akad. 2021, 14, 73-89. [CrossRef]

51. Turnock, D. Prospects for sustainable rural cultural tourism in Maramure y, Romania. Tour. Geogr. 2002, 4, 62-94. [CrossRef]

52. Antic, M.; Santic, D.; Kasanin-Grubin, M.; Malic, A. Sustainable Rural Development in Serbia-Relationship between Population Dynamicss and Environment. J. Environ. Prot. Ecol. 2017, 18, 323-331.

53. Jeong, J.H. Involution of tradition and existential authenticity of the resident group in Nyuh-Kuning village. J. Tour. Cult. Chang. 2021, 1-20.

54. Schuckert, M.; Wu, J.S. Are neighbour tourists more sensitive to crowding? The impact of distance on the crowding-out effect in tourism a research paper submitted to the Tourism Management. Tour. Manag. 2021, 82, 104185. [CrossRef]

55. Font, X.; English, R.; Gkritzali, A.; Tian, W.S. Value co-creation in sustainable tourism: A service-dominant logic approach. Tour. Manag. 2021, 82, 104200. [CrossRef]

56. Lane, B. Sustainable rural tourism strategies: A tool for development and conservation. J. Sustain. Tour. 1994, 2, 102-111. [CrossRef]

57. Mottiar, Z. The importance of local area as a motivation for cooperation among rural tourism entrepreneurs. Tour. Plan. Dev. 2016, 13, 203-218. [CrossRef]

58. Panyik, E. Rural tourism governance: Determinants of policy-makers' support for tourism development. Tour. Plan. Dev. 2015, 12, 48-72. [CrossRef]

59. Tirado Ballesteros, J.G.; Hernández Hernández, M. Assessing the Impact of EU Rural Development Programs on Tourism. Tour. Plan. Dev. 2017, 14, 149-166. [CrossRef]

60. Robinson, J.; O'Connor, N. Ballyhoura-A case study of cohesive rural tourism planning in Ireland. Tour. Plan. Dev. 2013, 10, 307-318. [CrossRef]

61. Martín-Martín, J.M.; Prados-Castillo, J.F.; Jiménez Aguilera, J.d.D.; Porras González, E. Interferences generated on the well-being of local communities by the activity of online platforms for tourist accommodation. J. Sustain. Tour. 2020, 1-20. [CrossRef]

62. Osinubi, T.T.; Osinubi, O.B.; Tabash, M.I.; Ajayi, A.O.; Tran, D.K. The Impact of Corruption on Tourism Sector in Nigeria: Empirical Insights by Using an Autoregressive Distributed Lag Bounds (ARDL) Testing Approach. Int. J. Hosp. Tour. Adm. 2021, 1-20. [CrossRef]

63. Alola, U.V.; Alola, A.A.; Avci, T.; Ozturen, A. Impact of corruption and insurgency on tourism performance: A case of a developing country. Int. J. Hosp. Tour. Adm. 2019, 1-17. [CrossRef]

64. Bourlon, F.; Gale, T.; Adiego, A.; Álvarez-Barra, V.; Salazar, A. Grounding Sustainable Tourism in Science-A Geographic Approach. Sustainability 2021, 13, 7455. [CrossRef] 
65. Çiftçioğlu, S.; Sokhanvar, A. Can specialization in tourism enhance the process of sustainable economic development and investment in East Asia and the Pacific? Int. J. Hosp. Tour. Adm. 2021, 1-24. [CrossRef]

66. Park, D.B.; Yoon, Y.S. Developing sustainable rural tourism evaluation indicators. Int. J. Tour. Res. 2011, 13, 401-415. [CrossRef]

67. Karahan, F.; Davardoust, S. Evaluation of vernacular architecture of Uzundere District (architectural typology and physical form of building) in relation to ecological sustainable development. J. Asian Archit. Build. Eng. 2020, 19, 490-501. [CrossRef]

68. Litvin, S.W.; Smith, W.W. International Travel and Coronavirus: A Very Early USA-based Study. Int. J. Hosp. Tour. Adm. 2021, 1-7. [CrossRef]

69. Ito, E.; Higham, J. Supplemental tourism activities: A conceptual framework to maximise sport tourism benefits and opportunities. J. Sport Tour. 2020, 24, 269-284. [CrossRef]

70. Mahmoudi, B.; Haghsetan, A.; Maleki, R. Investigation of obstacles and strategies of rural tourism development using SWOT Matrix. J. Sustain. Dev. 2011, 4, 136. [CrossRef]

71. Su, M.M.; Yu, J.; Qin, Y.; Wall, G.; Zhu, Y. Ancient town tourism and the community supported entrance fee avoidance-Xitang Ancient Town of China. J. Tour. Cult. Chang. 2021, 1-23. [CrossRef] 